\title{
SOME INTERNET MARKETING APPROACHES
}

\author{
Lieutenant-colonel, professor doctor Gheorghe Minculete,minculetegh@yahoo.com \\ National University of Defense "Carol" Bucharest \\ Ph. Doctor Marius Adrian RADUCEA,mraducea@yahoo.com \\ University "Valahia” Târgovişte
}

\begin{abstract}
Developing fast, the Romanian consumer is getting used to select his media" according to Cristian Parvan, Online Media manager for Zenith Media. Due to this fact, about one million users have changed their passive watching into exclusive searching the Internet in the past year. This comes as a reflective task both for advertising companies and for their customers.
\end{abstract}

As any other new management theory, marketing goes on keeping in steps with new technologies. Therefore, it moves towards virtual when attempting to convert new prospects, after invading traditional networks (audio visual, press, outdoor and indoor ads, PR events). This is how the concept of online marketing has just entered Romanian market, which is yet considered a new one, no matter the large number of users (according to studies, there were over five millions last year). Online marketing helps companies to achieve goals such as: brand awareness and brand attitude towards the product.

Virtual environment and digital technology have shaped the media, replacing cinema with home cinema and analogue radio with online radio broadcasting.

\section{Mass marketing to relationship marketing}

In a world where the prospect is assaulted with hundreds of ads for non essentials a day, marketing specialists have become more and more sophisticated: instead of mass marketing, which has no control of purchasing decisions, they moved towards "one to one" marketing for a more personalized contact.

What is to be pursued from the so-called "one to one" marketing?

- The company becomes more proactive to the customer's needs;

- As a result, this should lead to a greater satisfaction of the customer;

- The chances of keeping the customers are increasing and also the income of the company.

A brief analysis of the two approaches' features shows evident differences and the advantages of the last.

If, in mass media, we operate on a medium customer, in"one to one" marketing he becomes an individual one. In mass marketing, the customer is an anonymous person whereas in the second case we have the profile and we fulfill his needs in a better way. Instead of mass production and distribution, we speak of individualized and mass advertising turns into individualized messages focused on the particular customer.

\footnotetext{
${ }^{1}$ Virginia Hristu, "How to bring marketing onto Internet', published in 'Bilant', $19^{\text {th }}$ July 2006
} 
Finally, the most important thing for any business is to point to profitable customers. On short, if mass marketing attracts customers, relationship marketing keeps them. It is so developed a kind of marketing, which particularize each customer, focusing on the connection between him and the company.

Speaking of profit, it is said that a new way of working developed together with relationship marketing: the customer profit analysis, which ensures an audit for the portfolio of customers.

Focusing on profitable customers, the theory according to which selling implies profit becomes out of time. Now, the company's goal is to keep profit making customers, rationalizing the ones with no profit. $^{2}$ Companies will now focus on developing techniques for maintaining such customers.

\section{Unifying customers' databases}

Relationship marketing and management have found prospects in Romania, if we are to take into account the customer relationship management (CRM) launched by IT companies on the market. The fundamental problem of relationship marketing is that, a company generally keeps three data basis for its customers, independently developed by the three teams: marketing, selling and relationship (after purchasing assistance). It surely happened to you to buy a product and to be mistreated when asking for assistance, as if they were but then first in touch with you.

The essence of a relationship management is focusing these data basis in a single central one, so that, at any time, an employee may have the customer's coordinates and history. Each department collects information on customers in a particular way. This is the occidental model adopted by important companies. They come up to the conclusion that it is more efficient regarded both to costs and internal resources and every employee has a rapid access to the customer's data.

\section{The one- to- one relationship with the customer}

The advantage of "relationship" marketing consists of communicating with the prospect in a long-term relationship, more profitable than singular transactions. The advantages are obvious because:

- Getting new customers might be expensive;

- Loyal customers tend to spend more and their supplying costs less;

- A satisfied customer might well recommend the product to others;

- Customers accept a premium price from a previous tested and trusted producer.

On the whole, relationship marketing allows creating an exact profile of the prospect and the relationship company - customer becomes a one- to- one long-term relationship.

Virtual environment offers an excellent opportunity to manifesting relationship marketing by encouraging interaction with the prospect, personalized messaging and a relevant feedback.

The concept of "permission marketing"(a form of relationship marketing), developed by Kinecto in the last three years, refers to encouraging customers into a long-term relationship, making them a part of the interactive marketing campaign. "One cannot communicate with the

\footnotetext{
${ }^{2}$ Daniel Micu, marketing professor at Bucharest School of Management, MBA Canadian Program
} 
customer without his permission; if he blocks the channel, the company is lost" underlines professor Micu . ${ }^{3}$

And which is the most appropriate communication channel than Internet? The customer is trained, he is waiting for personalized messages from the company to refer to some products or services (for instance, those who want purchasing a car or an insurance would turn to an appropriate site or would ask for newsletters).

In the beginning of 2000, the idea of "dot com" companies was taken by some Romanian enthusiastic ones. They launched projects on creating websites, newsletters and news portals. In the autumn of 2002.

Radu Ionescu set "Kinecto Permission Marketing" developing permission-marketing campaigns on a brain new market. "Although I didn't know what online communication meant, looking back, it seems that I have made a pioneer's job, I somehow felt that, this way, the newsletter might have good results" says Radu Ionescu. ${ }^{4}$

\section{A pioneer of online marketing}

Corporate newsletter was Kinecto's first product, firstly meant for consulting and training companies because it fitted better to them in their open markets. Then, Kinecto turned to banks, auto producers and chemist's networks that keep in touch with customers and marketing specialists (Help Net Chemist's) and diversify the offer through online marketing strategies.

For consulting, human resources or training companies, mostly based on experts, newsletter proves to be a good instrument in business setting.

At that previous moment, 2003, the market didn't understand the product. "Companies weren't fully aware of this product's utility (newsletter), its cost or how to evaluate a budget, it was completely new" says Radu Ionescu. The advantage of Kinecto was that the manager new how to blend marketing and sales concepts when promoting its services.

What is to be earned by approaching to the prospect in the so-called relationship marketing?

- The company (producing goods or services) becomes more proactive, has a better reaction to the customer's needs;

- As a result, the customer should be more satisfied;

- The chances of keeping the customer and company's income are improving.

\section{Why do we need a newsletter?}

It is essential for a company to understand the selling process so it could manage from the marketing point of view and to know how to promote the newsletter.

There were also customers who, after tens of selling meetings, considered that newsletter isn't useful and not even free. Those who understood used to have a profit because, in the beginning, the impact of a newsletter was greater than now, when market is full of such products.

Respective to investment, the costs are low: creating a newsletter costs between 200 and 300 euros while the costs per a newsletter edition, monthly in general, rise between 200 and 500 euros, if the company also takes care of conceiving texts and distributing towards an existing customers database.

\footnotetext{
${ }^{3}$ Ibidem

${ }^{4}$ Virginia Hristu, "How to bring marketing onto Internet", published in "Bilant", $19^{\text {th }}$ July 2006
} 
The real problem of companies, which are interested in developing a newsletter, is naming a person from the company - either in the marketing or production departments and sometimes even the general manager- to collaborate in the product conceiving and periodically supply the necessary data, in a friendly form to be included in the newsletter. Among all, time resource proved to be the most expensive, more companies abandoning this modern communication mean particularly for this reason. ${ }^{5}$

Even though it costs less than a classic advertising company, producing and distributing a newsletter takes a lot of time. In other words, newsletter generates business for big companies, such as cars and banking. Practically, there are two types of effects in generating business, according to Radu Ionescu, managing director Kinecto Permission Marketing:

- Exactly as in the sales process, after the newsletter offers case studies, the prospect becomes more and more interested, he begins to understand the product "sold" through newsletter and he is eager to renew the deal;

- After communicating with the prospect, it is less probable that he forgets you and sometimes he returns in a year or two for purchasing.

\section{Which is the tip for a successful newsletter?}

An essential element is the accuracy of the database: Kinecto consultants always ask the customer where have they found the information, who are the prospects and which are the circumstances they get in touch in, just to make sure they are those personalized, profit generating prospects and the information about them are valid.

The actuality of databases is again important. For example, in the case of the car dealer, if you include the dates of the customers who came to the showroom three years ago but exclude those who visited you last week, you are in the probable situation of loosing - those from three years ago might have lost the country or they have already bought a car, not to mention a possible change of address or phone number.

Radu Ionescu points out: "Design helps but content sells", so, the accent goes on the content. We experimented the example of some traveling agencies, which assaults customers with the so-called "'offers". It is, of course, irrelevant, because not all the customers need the same offers at the same time.

Speaking of content, it is important for the company to come out in useful approaches - in the case of traveling agencies, presenting some practical pieces of advice for prospects, such as where to go shopping in X country, which are the particular products in country $\mathrm{Z}$ or which is the difference between a 3 stars hotel and a 4 stars one. These are pieces of valuable information, more than a general offer, which is to be found in any other traveling agency.

It is to be said that, prior to designing a website or newsletter, the company has to answer two essential questions: which is the purpose of the newsletter (which is the message to be transmitted) and - if there is a negative feedback from the prospects - which are the problems to be confronted to, in order to get a professional approach. Not less important, the newsletter has to be attractive, with impact titles for catching the eye and mind of the prospect.

\section{The site - an aid for the company's trustworthy}

\footnotetext{
${ }^{5}$ Ibidem
} 
Ensight Management Consulting, one of the dynamic leaders on the market, has recently closed a deal in rebranding for a new face of the site and the newsletter Ensight.The main three reasons for using these online marketing tools are -according to the lawyer and company's partner, Dan Mihai - as follows: visibility in retaining customers, business communities, press, students; brand and company acceptance; training the market respective to the opportunity and the benefits of integrator business consulting solutions.

"Our business (consulting) is not using the site as an instrument for selling services" says Dan Mihai. In consulting, the customers' recommendations are the main sources which generate new projects and/or new customers. The site is more like a support for the company's trustworthy, which offers the prospects ample information on company, tendencies and studies respective to different industries or news.

"According to statistics, the number of unique visitors have doubled within three months from launching the site and we're expecting a triple growth comparing to the first month" said the company's manager. In order to measure the impact of the site on its visitors, Mr. Dan Mihai said that Ensight uses one of the most performing searching engines in the world, which allows monitoring both visitors' home area and their evolution of visiting in time. ${ }^{6}$

Online communication for commercial purpose applies within the electronic commerce law number 365/2002, republished. According to this law, some businessmen admit that the Ministry of Communication and Technology should have set a department for solving the abuses, which hasn't come up yet.

There were situations when customers complained on companies using their addresses, forgetting that, years ago they filled in forms on a site.

Apart from the possible legal aspects of virtual communicating with the consumer, the manager of Kinecto is more concerned of the perception of the product (website, newsletter) on the prospects.' The problem doesn't occur from the fact that you get notices from clients but the fact that they don't read the newsletter, ignoring it. For many, communication has no effect" underlines Radu Ionescu.

"Respective to measuring the results, it is difficult to say if somebody has lost a business if he sent a newsletter. This relation with the customer allows brand awareness, brand attitude and an open way in online communication and it would be extremely advisable in the case of public institutions" says Radu Ionescu. The positive effects are noticeable: Help Net have experimented an increase of general awareness and new sales on existing customers since the first newsletter.

Paradox ally, developing local online marketing is influenced by the phenomenon of globalization, Romanian customer being more interested in accessing international sites for information which is not to be found on the local market. So, the time spent absorbing the information becomes limited. In fact, the real competition is for getting the longest time spent by the prospect.

Development on the Romanian market resembles the "snowball" effect. Once a competitor decides on developing his image online, to re- launch his site or to produce a newsletter for different targeted public, the others are immediately following his steps. This is particularly the case of banking system, where the concurrence is tough on the retail segment.

A lot of multinational companies still prefer the classical approach and do not invest in online promoting. For names like Danone, Henkel or Pepsi, classical advertising is successful in

\footnotetext{
${ }^{6}$ Ibidem
} 
the conditions of a continuously growth in selling. "For a company that invests between 5 and 20 millions euro/year in advertising, the alternative of just 100.000-200.000 euro/year on a newsletter implies a great time consuming and it is not justified" considers Radu Ionescu. As long as, in some industries, there is less concurrence on the market, the presence online cannot generate significant business. Only in the case of a saturated market, when big companies will increase just $1-2 \% / y e a r$, they will take into account the usage of alternative communication with customers. $^{7}$

A company's site may be the first contact element before the potential consumer to decide on buying a product or a service. Piraeus Bank has decided in 2005 to re-launch their site as an integrator part in the communication strategy. "The main target was the transparency towards the present and potential clients and the desire to inform them before coming to the bank. A bank site has to inform" declares Cristina Popa, marketing assistant.

Prospects being well-informed, they want to find"which are the services and costs of the bank" on the site. In order to scale efficiency, reports are made every year on the position of Piraeus Bank comparatively to others. The results were unbelievable: so far, over 3.500 people have accessed online for the products of the bank and the number of daily visitors is more than 800. So, foreseeing the clients' needs, the bank will soon implement new functions, which are to allow online applications for some products and services but it doesn't intend to replace its subsidiaries with online business.

\section{Bibliography:}

1. Virginia Hristu, 'How to bring marketing onto Internet', published in 'Bilant', $19^{\text {th }}$ July 2006

2. Daniel Micu, marketing professor at Bucharest School of Management, MBA Canadian Program

3. Philip Kotler on marketing, 'How to create, to earn and to dominate markets', Curier Marketing Publishing House, Bucuresti, 2003.

4. Philip Kotler 'Marketing Management' IV th Edition, Bucharest, 2005

5. Philip Kotler, Gary Armstrong 'The Principle of Marketing', Teora Publishing House, Bucharest,2004

\footnotetext{
${ }^{7}$ Ibidem
} 